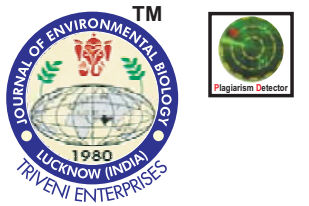

\title{
Tree species composition and population structure of a secondary tropical evergreen forest in Cachar district, Assam
}

Authors Info

\section{B. Borogayary, A.K. Das*} and A.J. Nath

Department of Ecology and Environmental Science, Assam University, Silchar - 788 011, India

${ }^{*}$ Corresponding Author Email : asheshkd@gmail.com

Key words

Population structure Tropical forest Tree species

Publication Info

Paper received : 18.10 .2016

Revised received : 18.03 .2017

Re-revised received : 10.04.2017 Accepted : 27.06.2017

\section{Abstract}

Aim : Species composition, structure and dynamics are becoming an important tool to estimate the level of adaptation to the environment and providing useful information to their ecological significance. The present study was carreid out to determine the tree species composition, diversity and population structure of a secondary tropical evergreen forest in Cachar district, Assam.

Methodology : Assessment of tree was carried out in a permanent plot ( 1 ha) subdivided into one hundred $(10 \mathrm{~m} \times 10 \mathrm{~m})$ quadrats for enumeration of all trees $(\geq 10 \mathrm{~cm})$ girth at breast height. Girth was measured at $(1.37 \mathrm{~m})$ above ground level and trees of girth size $(\geq 10 \mathrm{~cm})(\mathrm{gbh})$ were taken. The tree species were collected and herbarium was prepared and identified from collection of herbaria at the Botanical Survey of India, Eastern Regional Centre, Shillong.

Results : A total of 2152 stems ha ${ }^{-1}$ belonging to 52 species, 43 genera and 28 families with a total basal area of $23.80 \mathrm{~m}^{2}$ ha ${ }^{-1}$ were recorded. The most dominant families were Sapotaceae, Myrtaceae, Fagaceae, Euphorbiaceae and Clusiaceae according to the Family Importance Value (FIV) index. Palaquium polyanthum, Memecylon celastrinum, Castanopsis purpurella, Artocarpus chaplasha and Cynometra polyandra were five most dominant and important species in the tropical secondary forest. The girth size of all species combined followed the reverse-J-curve, typical of uneven-aged mixed forests.

Interpretation : The present study could be useful for understanding the changes in the species composition during the course of development in a secondary tropical forest dominated by Palaquium polyanthum (Sapotaceae).

A total of 2152 individuals of 28 families, 43 genera and 52 tree species were recorded in a one hectare permanent plot

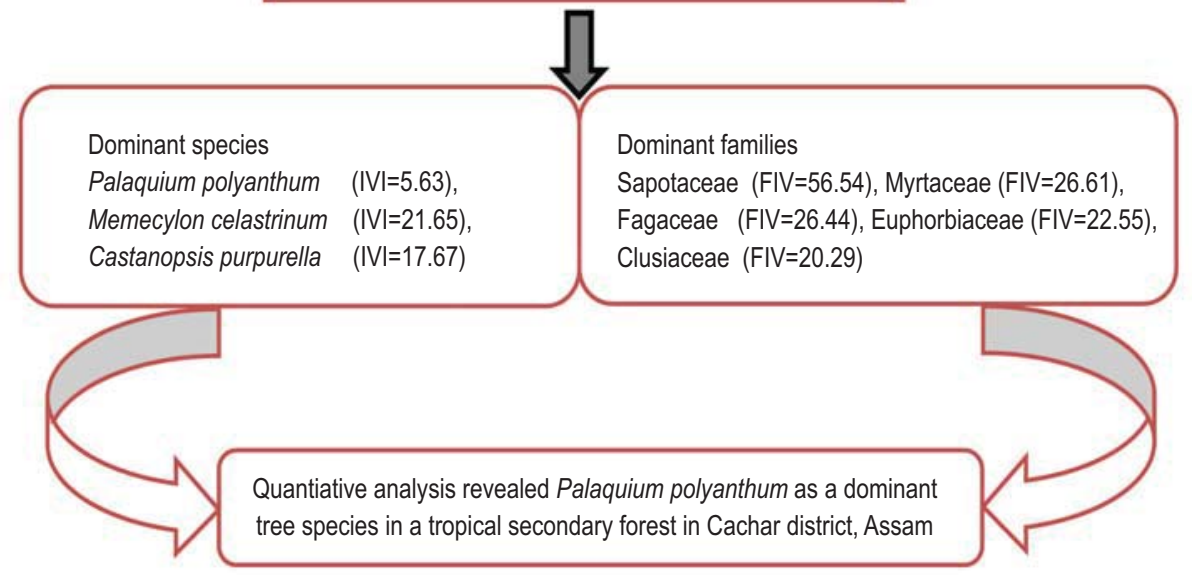




\section{Introduction}

Tropical secondary forests play an important role in global carbon cycle and are becoming prominent in the landscape of tropical countries. It is estimated that in the tropics the area of secondary forests was recently 850 million hectares, and in the future this amount is likely to increase deastically (ITTO, 2002). Increase of tropical secondary forest has resulted due to logging of tropical primary forests for its timber to supply wood and other products. Secondary forests form a principal component of the forest types in the Central Himalayan region including Northeastern states of India. Secondary forests are those forests that regrow largely through natural processes after significant anthropogenic disturbance of the primary forest structure at a single point in time or over an extended period of time, and place prominently a major changes in tree diversity and/or species composition with respect to nearby original forests on similar sites (Chokkalingam and De Jong, 2001). However, the secondary tropical forest also becomes important for conservation value as most of the old-growth tropical forests are logged or cleared. Secondary forest vegetation can provide important resources for nesting, foraging, and protection for a variety of animal and plant taxa. The secondary forests are reflected in their structure and extent of vegetative cover, as well as their composition in terms of dominant species. As compared to primary forest species, majority of secondary forest species in tropics are thought to be growing fast and light-demanding because retention and availability of light and nutrient in secondary forests is usually more variable in comparison to primary forests. In tropical landscape, secondary forests are gaining prominence for their socio-ecological functions. About $30 \%$ of tropical forest areas now constitute secondary forests due to significant human and natural disturbance of the primary forest (Emrich et al., 2000). In India it is estimated that about $45.8 \%$ of the forest area of the country and about 32 million ha constitute secondary forests (Chaturvedi, 1992).

The Cachar district of Assam has relatively remained unexplored, because most of the forests of this region are under anthropogenic pressure (such as extraction of timber, fuelwood collection, cattle grazing, etc.) to restraint its resources for the development of socio-economic purposes (Borah and Garkoti, 2011). If this present trend continues and more effective management strategies are not implemented, most of the native vegetation in this region will be diminished or replaced by successional communities (Proctor et al., 1998). Keeping in view the proper management strategy of forests in this region, in the present study, tree species composition and population structure of a secondary tropical evergreen forest in Cachar district, Assam, Northeast India was evaluated.

\section{Materials and Methods}

The present study was carried out in Loharbond Forest Range at Sonachera in Cachar district of Assam, Northeast India. Warm and wet humid climatic condition with frequent rainfall is the characteristics feature which supports tropical wet evergreen forests in the region. The study area is sub-tropical, warm and humid. The south west monsoon season mainly influence most of the precipitation which occurrs during the month of May to September. The average rainfall of this area is about $2290 \mathrm{~mm}$, most of which is received during the month of May to September. Temperature ranges between $13 \cdot 5-34 \cdot 5^{\circ} \mathrm{C}$.

The studied forest is a "Cachar Tropical Evergreen Forest" type dominated by Artocarpus chaplasha, Castanopsis purpurella, Cynometra polyandra, Memecylon celastrinum and Palaquium polyanthum. The selected secondary forest is more than 35-year-old and the forest had been logged for fuelwood collection and timber extraction. Tree inventory was carried out in a permanent plot ( $1 \mathrm{ha}$ ) which was subdivided into one hundred $(10 \mathrm{~m} \times 10 \mathrm{~m})$ quadrats for enumeration of all trees $(\geq 10 \mathrm{~cm})$ and its girth were measured at breast height $(1.37 \mathrm{~m}$ ) with the help of measuring tape, those with buttresses were measured above the latter. Tree species were collected either in flowering and fruiting stage and herbarium was prepared. The species were identified by using regional floras (Kanjilal et al., 1934-40) and by consulting herbaria of the Botanical Survey of India, Eastern Regional Centre, Shillong.

The vegetation was analyzed following the method of Mueller - Dombois and Ellenberg, (1974). Importance Value Index (IVI) was calculated by summing up three parameters relative density, relative frequency and relative dominance. Family Importance Value (FIV) was calculated by summing the relative diversity, relative density and relative dominance (Mori et al., 1983). Population structure of trees was analysed across 13 girth classes ranging from $10-20 \mathrm{~cm}$ to $130-140 \mathrm{~cm}$. Shannon's diversity and Simpson's dominance indices were calculated according to (Magurran, 2004). The abundance to frequency ratio was calculated following Curtis and Cottam (1956). Distribution patterns were considered to be $<0.025$ regular distribution, 0.025-0.05 random distribution and $>0.05$ contagious distribution (Whitford, 1948). Data were managed and analysed using MS Excel 2010.

\section{Results and Discussion}

A total of 28 families, 43 genera, 52 tree species and 2152 individuals ( $>10 \mathrm{~cm}$ girth) were enumerated from 1 ha plot of a secondary tropical evergreen forest stand of Cachar district, Assam. Palaquium polyanthum locally known as "Kurta" was analyzed with Importance Value Index (IVI=53.63) in the present study site as the ecologically most dominant and significant tree species. The other co-dominant species were Memecylon celastrinum (IVI= 21.65), Castanopsis purpurella (IVI= 17.67), Artocarpus chaplasha (IVI= 15.85) and Cynometra polyandra (IVI=15.49) (Fig. 1). The present findings resemble the dominant species Palaquium ellipticum reported from the tropical wet evergreen forests of the Western Ghats (Giriraj et al., 2008) and Palaquium quercifollium in tropical rainforest of Central Sulawesi, Indonesia (Pitopang, 2012). Two IUCN Red list categories of tree species were recorded in the studied forest of which Aquilaria 


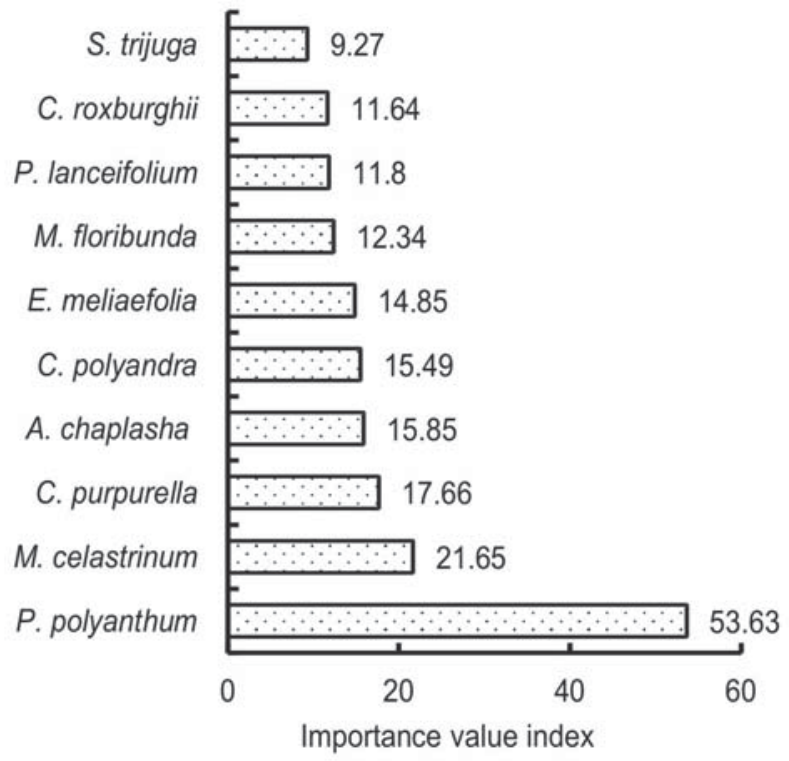

Fig. 1 : Importance value index of ten dominant tree species

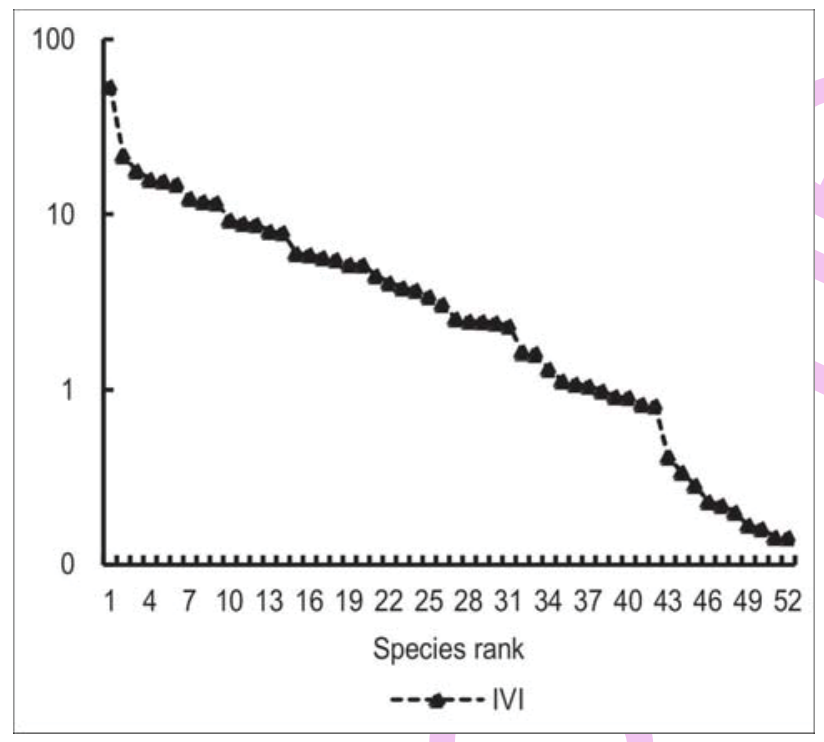

Fig. 3 : D-D curve of the study site

malaccensis was listed as vulnerable and Vatica lanceifolia as critically endangered under criteria $\mathrm{A} 1 \mathrm{~cd}, \mathrm{C} 2 \mathrm{a}$, version 2.3 of (IUCN, 2015). Both species are commercially important for aromatic agar wood and oleoresin. The presence of Vatica lanceifolia was also reported from the Tropical semi-evergreen forest of Hollangapar Gibbon Wildlife Sanctuary in Assam (Sarkar and Devi, 2014).

Taxonomically well represented families include Myrtaceae (6 species), Euphorbiaceae (5 species), Fagaceae,

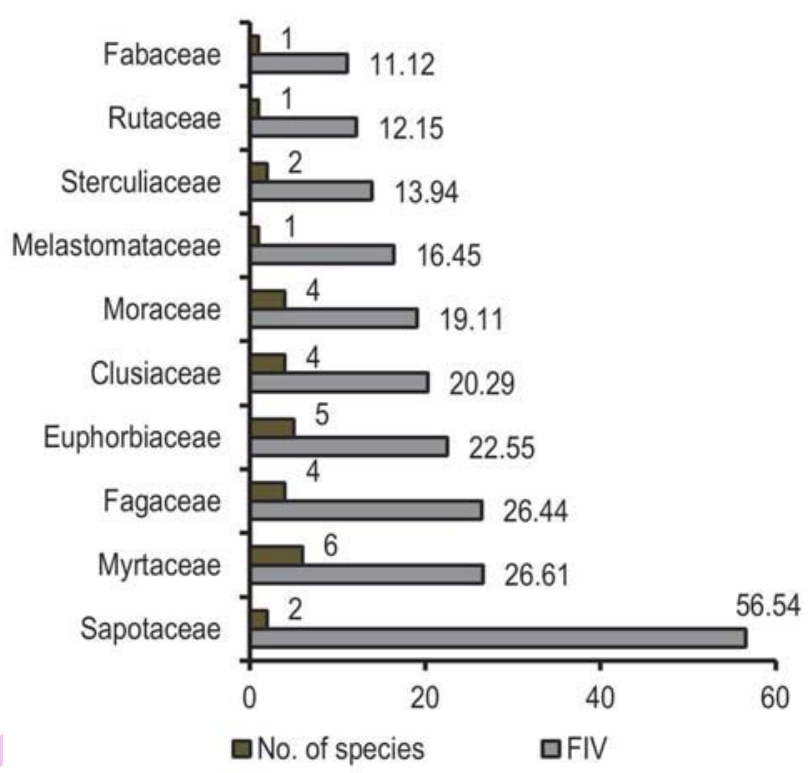

Fig. 2 : Family dominance based on species richness and family importance value

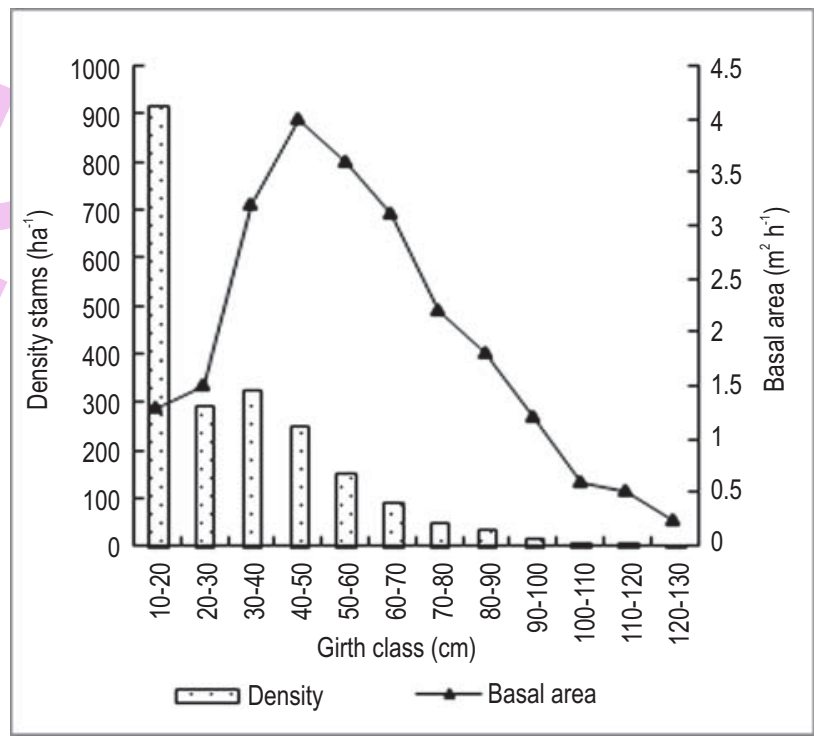

Fig. 4 : Relationship between density and basal area of the study site

Clusiaceae and Moraceae (4 species each), Verbenaceae and Lauraceae (2 species each) (Fig. 2). In the present study, eighteen families were represented by only one species. The most ecologically significant family as determined by the Family Importance Value (FIV) was Sapotaceae with a value of 56.54 followed by Myrtaceae (FIV= 26.61), Fagaceae (FIV= 26.44), Euphorbiaceae (FIV= 22.55), Clusiaceae (FIV= 20.29), Moraceae (FIV = 19.11) and Melastomataceae (1 species, FIV= 16.45) (Fig. 2). The result of the present study resembles with the dominant family of tropical evergreen forest reported from 
Northeast India (Nath et al., 2005; Parthasarathy et al., 2008). Joglekar et al. (2015) reported similar findings for dominant family in Koyna Wildlife Sanctuary, Northern Western Ghats of India. Sapotaceae family was observed as the most dominant family due to the presence of $P$. palaquium that covered $31.36 \%$ of total number of individuals of trees encountered in the present study.

In the present study, most of the species were distributed contagious following random distribution while few species were regular in distribution. Out of 52 tree species, 38 (73.07\%) species were contagious in distribution, followed by random distribution of $12(23.07 \%)$ species and only $2(3.84 \%)$ species were regular in distribution. Greater proportion of contagiously distributed tree species made the forest community highly patchy in nature. Most common distribution pattern is the contagious distribution in nature (Odum, 1971). The clumping of individuals of a species may be due to insufficient mode of seed dispersal or when death of a tree creates a large gap encouraging recruitment and growth of numerous saplings as in the present studied secondary forest dominated by young trees of Palaquium polyanthum.

Dominance-distribution pattern among the tree species showed lognormal distribution pattern (Fig. 3) signifying high equitability and low dominance among the species. Lognormal distribution is approached at later stages of succession where species diversity is high and community resources are shared by many species (Bazaz, 1975). The lognormal dominancedistribution curve, as found in the present study, signifies equitability and stability of the community.

A gradual decrease in girth class distribution was observed with increasing size class of trees from 10 to $133.1 \mathrm{~cm}$ girth at breast height. Girth class density - distribution curve of all species combined resulted typical reverse-J-shaped. Similar trends of density-girth class distribution was observed in Trishna Wildlife Sanctuary of Tripura in north east India (Majumdar and Datta, 2015). Young trees (gbh 10-20 cm) contributing about (920 trees ha ${ }^{-1}$ ) $42.7 \%$ of total tree density were most abundant (Fig. 4). Of the total tree density higher girth classes $(>50 \mathrm{~cm}) 359$ trees ha $^{-1}$ account for contributing $16.68 \%$. 40-50 cm girth class $(250$ trees $\left.\mathrm{ha}^{-1}\right)$ represent the highest basal area $\left(4.00 \mathrm{~m}^{2} \mathrm{ha}^{-1}\right)$ as compared to other girth class and followed a hump-shaped pattern of distribution curve. Basal area distribution of this type of curve may indicate the improper and unsustainable management of trees in the forest (Alelign et al., 2007). The total basal area of all size classes of trees combined was $23.80 \mathrm{~m}^{2} \mathrm{ha}^{-1}$. An abrupt decrease in density and basal area distribution of trees in higher girth classes (> $50 \mathrm{~cm}$ girth) may be due to anthropogenic and unplanned felling of trees. One significant characteristic of forest was the prevalence of the dominant species, $P$. polyanthum, in all size classes, except higher size class. In one hectare, permanent plot, the basal area value of the individual tree species ranged from 0.14-3.68 $\mathrm{m}^{2} \mathrm{ha}^{-1}$. The present trend resembles the findings of other studies in tropical forests of northeastern region (Nandy and Das, 2013) and tropical forests of Western Ghats (Swamy et al., 2010). One of the reasons for high density of trees in lower girth class is that the forest was in secondary successional stage.

Species diversity is an important attribute of a natural community that influences functioning of an ecosystem. The diversity index value in the present study as computed using the Shannon-Wiener index of diversity was 3.25 , based on IVI values that could be comparable with the diversity value of Dipterocarp forests reported from the Western Ghats, India (Devi Prasad and Al-Sagheer, 2012). The studied secondary tropical evergreen forest showed high value as Shannon index values greater than 2 indicates of medium to high diversity (Barbour et al., 1987). The Simpson index showed a low value of 0.058 indicating low dominance.

Baseline data generated on secondary forest vegetation and composition is fundamental for conservation of natural areas which is a prerequisite to understand the overall structure and function of any ecosystem. Quantitative analysis of the forest vegetation in the present study may provide a baseline information for formulating proper conservation and management of regrowing secondary vegetation in the tropical forests of northeast India.

\section{Acknowledgments}

Infrastructural facilities provided by the UGC-SAP and DST-FIST assisted Department of Ecology and Environmental Science, Assam University, Silchar for carrying out research work is gratefully acknowledged. The authors acknowledge the University Grants Commission, Basic Scientific Research (UGCBSR), New Delhi, India for providing financial assistance to one of the authors (Birkhungur Borogayary). The authors acknowledge the help provided by the Botanical Survey of India, Eastern Regional Centre, Shillong for helping in identification of plant specimens. Authors are thankful to Mr. Babulal Goala for assisting in the field data collection.

\section{References}

Alelign, A., D. Teketay, Y., Yemshaw and S. Edwards: Diversity and status of regeneration of woody plants on the peninsula of Zegie, northwestern Ethiopia. Trop. Ecol., 48, 37-49 (2007).

Barbour, M.G., J.H.Burk and W.D. Pitts: Terrestrial Plant Ecology. Benjamin/Cummings Publishing Company, San Fransisco (1987).

Bazaz, F.A.: Plant species diversity in old field successional ecosystems in Southern Illionois. Ecology, 56, 485-488 (1975).

Borah, N. and S.C. Garkoti: Tree species composition, diversity and regeneration patterns in undisturbed and disturbed forests of Barak Valley, South Assam, India. Int. J. Ecol. Environ. Sci., 37, 131-141 (2011).

Chaturvedi, A.N.: Management of secondary forests. Wasteland News, 7, 40-44 (1992).

Chokkalingam, U. and W. De Jong : Secondary forest : A working definition and typology. Int. For. Rev., 3, 19-26 (2001).

Curtis, J.T. and G. Cottam: Plant Ecology Workbook. Burgess Publishing Co., Minneapolis, Minnesota (1962).

Devi Prasad, A.G. and N.A. Al-Sagheer: Floristic diversity of regenerated 
tree species in Dipterocarp forests in Western Ghats of Karnataka, India. J. Environ. Biol., 33, 791-797 (2012).

Emrich, A., B. Pokorny and C. Sepp : The Significance of Secondary Forest Management for Development Policy. TOB Series No. FTWF-18e. GTZ, Eschborn, Germany (2000).

Giriraj, A., M.S.R. Murthy and B.R. Ramesh: Vegetation composition, structure and patterns of diversity: A case study from the tropical wet evergreen forests of the Western Ghats, India. Edinb. J. Bot., 65, 1-22 (2008).

ITTO: ITTO guidelines for the restoration, management and rehabilitation of degraded and secondary tropical forests. ITTO in collaboration with CIFOR, FAO, IUCN and WWF, Yokohama, Japan (2002).

IUCN: The IUCN Red list of threatened species version 2015. IUCN Red List Unit, Cambridge, U.K. (2015).

Joglekar, A., M. Tadwalkar, M. Mhaskar, B. Chavan, K.N. Ganeshaiah and A. Patwardhan: Tree species composition in Koyna Wildlife Sanctuary, Northern Western Ghats of India. Curr. Sci., 108, 16881693 (2015).

Kanjilal, U.N., P.C. Kanjilal, A. Das, R.N. De and N.L. Bor: Flora of Assam. Vol. 1-5. Government Press, Shillong (1934-40).

Magurran, A.E. : Measuring Biological Diversity. Blackwell Publishing Sc. Ltd. (2004).

Majumdar, K. and B.K. Datta: Vegetation types, dominant compositions, woody plant diversity and stand structure in Trishna Wildlife Sanctuary of Northeast India. J. Environ. Biol., 36, 409-418 (2015).

Mori, S. A., B. M. Boom, A. M. de Carvalho and T. S. dos Santos: The ecological importance of Myrtaceae in an eastern Brazilian wet forest. Biotropica, 15, 68-70 (1983).

Mueller-Dombois, D. and H. Ellenberg: Aims and Methods of Vegetation
Ecology. John Wiley and Sons, New York (1974).

Nandy, S. and A.K. Das: Comparing tree diversity and population structure between a traditional agroforestry system and natural forests of Barak Valley, Northeast India. Int. J. Biodivers. Sci., Ecosyst. Serv. Manag., 9, 104-113 (2013).

Nath, P.C., A. Arunachalam, M.L. Khan, K. Arunachalam and A.R. Barbhuiya: Vegetation analysis and tree population structure of tropical wet evergreen forests in and around Namdapha National Park, northeast India. Biodivers. Conserv., 14, 2109-2136 (2005).

Odum, E. P.: Fundamentals of Ecology. $3^{\text {rd }}$ Edn., W. B. Saunders Co., Philadelphia(1971).

Parthasarathy, N., M.A. Selwyn and M. Udayakumar: Tropical dry evergreen forests of peninsular India : Ecology and conservation significance. Trop. Cons. Sci., 1, 89-110 (2008).

Pitopang, R.: Impact of forest disturbance on the structure and composition of vegetation in tropical rainforest of Central Sulawesi, Indonesia. Biodiversitas, 13, 178-189 (2012).

Proctor, J., K. Haridasan and C.W. Smith: How far north does lowland evergreen tropical rain forest go? Global Ecol. Biogeogr. Lett.,7, 141-146 (1998).

Sarkar, M. and A. Devi : Assessment of diversity, population structure and regeneration status of tree species in Hallongapar Gibbon Wildlife Sanctuary, Assam, Northeast India. Trop. Plant. Res., 1 , 26-36 (2014).

Swamy, P.S., S.M. Sundarapandian, P. Chandrasekar and S. Chandrasekaran : Plant species diversity and tree population structure of a humid tropical forest in Tamilnadu, India. Biodivers. Conserv., 9, 1643-1669 (2000).

Whitford, P.B.: Distribution of woodland plants in relation to succession and clonal growth. Ecology, 30, 199-208(1948). 